\title{
Influence of water level fluctuation on groundwater solute content in a tropical south Indian region: a geochemical modelling approach
}

\author{
P. J. Sajil Kumar ${ }^{1}$ (1)
}

Received: 22 August 2016/Accepted: 27 September 2016/Published online: 4 October 2016

(C) Springer International Publishing Switzerland 2016

\begin{abstract}
Groundwater levels in the Dharapuram region exhibited drastic seasonal changes. Hydrogeochemical analysis were performed on the groundwater samples collected during January (post-monsoon) and July (pre-monsoon) in 2009 to understand the chemical changes and related process encountered during the fluctuated water table. Dominant water type in the study area was $\mathrm{Na}-\mathrm{Cl}$ with smaller contributions from $\mathrm{Ca}-\mathrm{Cl}$ and mixed $\mathrm{Ca}-\mathrm{Mg}$ $\mathrm{Cl}$ type of water. Gibbs plot employed to differentiate the controlling mechanisms of hydrochemistry, which showed that rock-water interaction is the dominant process. However, bivariate plots identified silicate weathering is the major contributor to the rock weathering. Higher concentration of $\mathrm{Cl}$ in the groundwater is suggesting the anthropogenic sources to ionic chemistry. Precise examination of the hydrochemical changes with rise and fall in the water table showed three distinct behavior; the EC, increased with increasing water level (type 1), increased with decreasing water level (type 2) and no significant changes with WL fluctuation(type 3). Aqueous speciation modeling was carried out on representative samples. This shows that dissolution and deposition of the carbonate minerals, mixing of textile wastes and the irrigation return flow were the major processes prevailing in the study area. However, the changes in chemical kinetics encountered during seasonal water level fluctuation are also controlling the hydrogeochemistry of this hard rock terrain.
\end{abstract}

P. J. Sajil Kumar

pjsajil@gmail.com; pj.sajil@fu-berlin.de

1 Institute of Geological Sciences, Hydrogeology Group, Freie Universität Berlin, Malteserstr. 74-100, 12249 Berlin, Germany
Keywords Hydrochemistry · Water level fluctuation . Geochemical processes · Hard rock terrain · Southern India

\section{Introduction}

As in many parts of the world, groundwater chemistry in the semi-arid regions of Tamil Nadu is susceptible for seasonal variation due to alternate summer and monsoon seasons (Vasanthavigar et al. 2012; Rajmohan and Elango 2006). The quality of this resource is controlled by a series of closely related physical and chemical processes acting on the environment such as aerobic respiration, leaching of surface salts, ion exchange process, evaporation, silicate weathering, seawater mixing and residence time (Mohapatra et al. 2011). Apart from the above mentioned factors, physical factors such as temperature, rainfall and water level variation etc. have great effects on the hydrogeochemical processes and water quality. The primary use of hydrochemical analysis is the determination water quality for drinking and domestic, irrigation, industrial and environmental purposes. Elevated concentration of chemical parameters in the drinking water may badly affect either the human health or the acceptability of water (Zhang et al. 2012).

In the monsoon fed regions of India, the seasonal water level will be fluctuated mainly depending upon the amount of rainfall. This raise and fall in groundwater table may give rise to several chemical reactions and subsequent variation in the chemistry of groundwater. In general, the mixing of relatively fresh rainwater with the groundwater may improve the quality of the groundwater. However, this is may be reversed in certain regions; cause the dissolution of the aquifer matrix due to the water level rise. Groundwater chemistry and its seasonal variation were 
Fig. 1 Location map of the study area with sampling wells

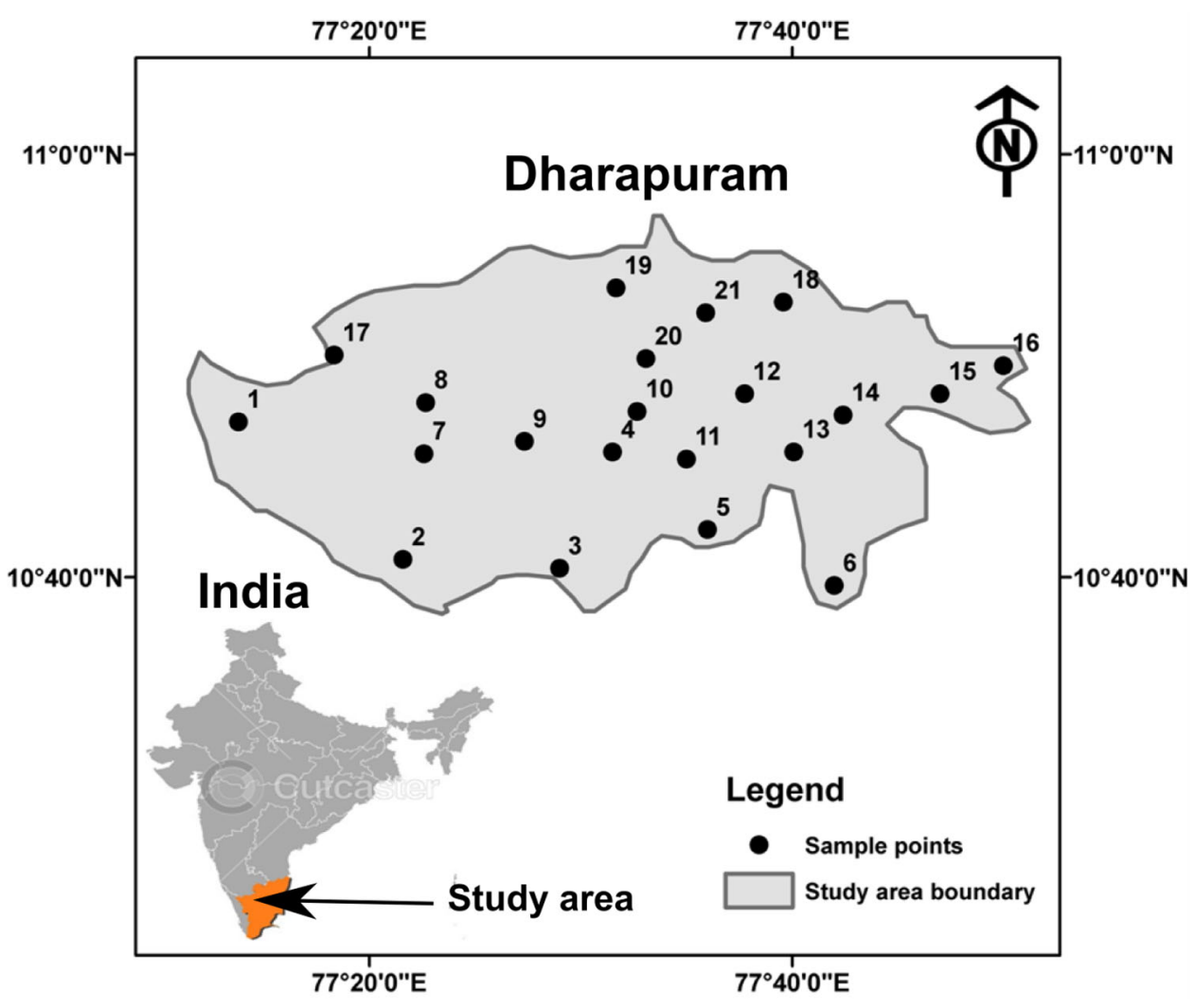

documented by several researchers from India and abroad (Bjerg and Christensen 1992; Laluraj and Gopinath 2006; Subba 2006; Giridharan et al. 2008; Holz 2009; Karmegam et al. 2010; Sajil Kumar et al. 2013; Arunprakash et al. 2014; Jayalakshmi et al. 2014). Rajmohan and Elango (2006) studied the groundwater chemistry and its relation with the water level fluctuations in Palar and Cheyyar river basins in Tamil Nadu. They have reported that major-ion chemistry is also greatly influenced by the water level fluctuations in different geological formations. The increase in salinity from post- monsoon to pre- monsoon in the Central Ganga plain is attributed to evaporation from water table, irrigation return flows, and anthropogenic activities and below average rainfall in the preceding monsoon season (Umar et al. 2009). Seasonal variation in lead, arsenic, cadmium and aluminium in groundwater in Dhemaji district, Assam were reported by Buragohain et al. (2010).

Since, the major portion of water supply in many regions in India depending on groundwater; the temporal changes in groundwater quality must be monitored regularly. Identification of the contamination sources and their prevention is very important in maintaining the quality water supply. In this context, this study investigates the hydrochemical changes in the groundwater with fluctuating water level of Dharapuram area in south India.

\section{Description of the study area}

Dharapuram is located Tiruppur district of Tamil Nadu marked by the East Longitude $\left(77^{\circ} 15^{\prime} 00^{\prime \prime}-77^{\circ} 55^{\prime} 00^{\prime \prime}\right)$ and North latitude $\left(10^{\circ} 38^{\prime} 00-77^{\circ} 56^{\prime} 00^{\prime \prime}\right)$ (see Fig. 1). This is a semi-arid region with a tropical climate. Temperature of the region is ranging from 20 to $40{ }^{\circ} \mathrm{C}$ and receives scanty rains as the area is situated on the leeward side of the mountain range Western Ghats (Arumugam and Elangovan 2009). The rainy season starts from October to December; southwest and northeast monsoons are the major rainy seasons. The northeast monsoon chiefly contributes to the rainfall and summer rains are negligible. Average rainfall of the study area is $600 \mathrm{~mm}$. Physiographicallay Dharapuram has an undulating terrain with varying topographical height between 290 and $320 \mathrm{~m}$ above MSL. Noyyal is a perennial river originates from the Western Ghats and flowing through the study area. Thirupur is the textile hub of India, the production id largely concentrated on small scale industries. Untreated effluents and dyes from these industries are the major medium of pollution.

Dharapuram taluk consist mainly hard rocks of high grade metamorphic in nature (see Fig. 2). These hard gneissic rocks are under lined by recent alluvium in certain pockets. The most common rock type of the area is Hornblende-biotite- gneisses (Arumugam and Elangovan 
Fig. 2 Geology of the study area

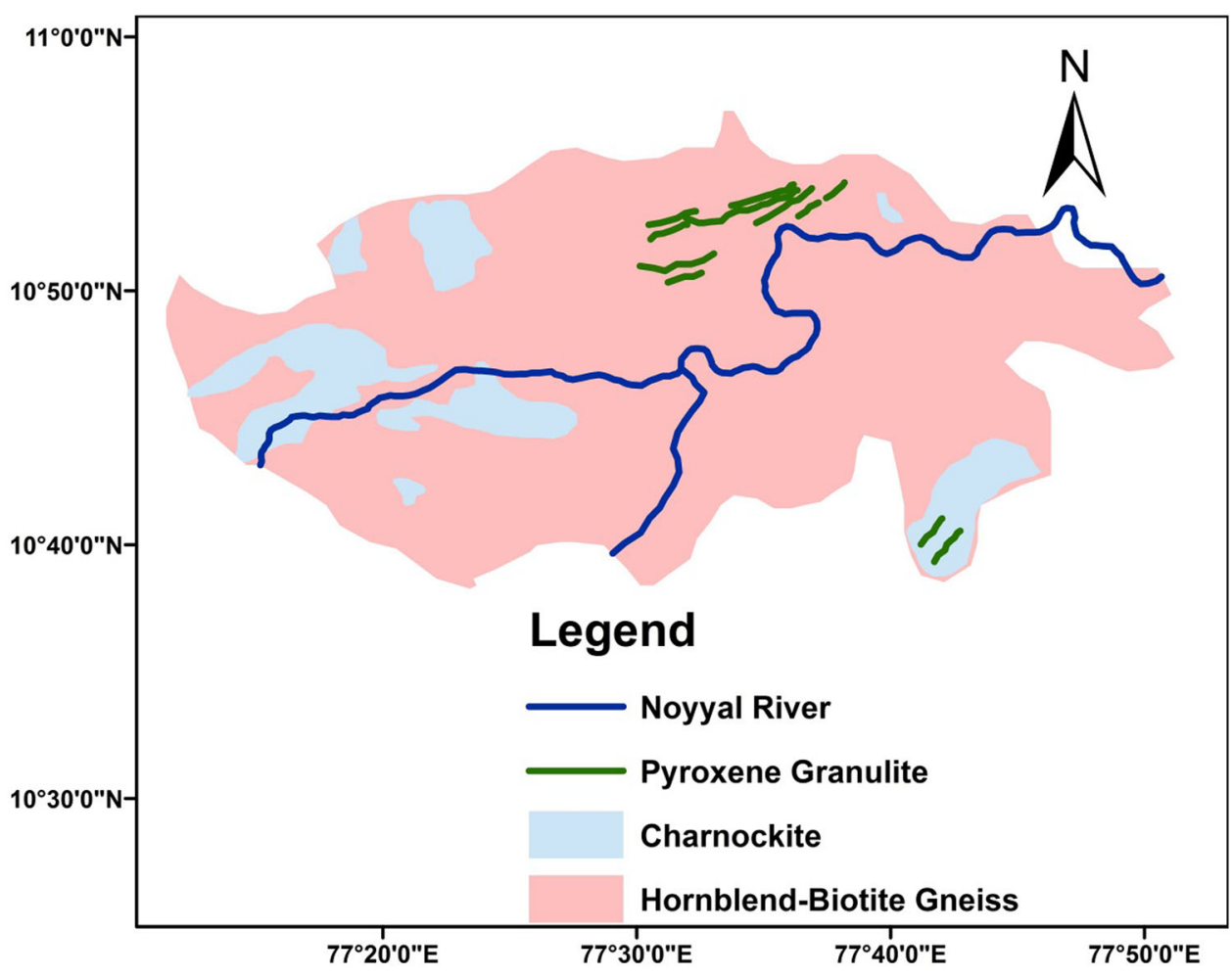

2009). Charnockites and pink-granite cover majority of the area. Soil types of the study area can be divided into Fine, Fine loamy, Loamy skeletal, Clayey loamy and none/absent. The land use can be classified as Built up, Agriculture, Water bodies and Waste land. Water supply of the major portion of the study area is derived from deep dug wells reaching 35-45 m below ground level. However in the past two decades electrification of wells increased the groundwater withdrawal and finally water table receded to $50-60 \mathrm{~m}$.

\section{Materials and methods}

A hydrogeochemical survey has been conducted and groundwater samples were collected from the Dharapuram Taluk. 21 wells were selected and the locations are marked accurately using a handheld GPS. A total of 42 groundwater samples were collected for two seasons January (post-monsoon) and July (pre-monsoon) in 2009. Wells were pumped out prior to get the representative sample from the aquifer. Water samples were collected in precleaned polyethylene bottles (1L capacity) and sealed to avoid the atmospheric contact. Pre-cleaned bottles were used as container. Analysis was carried out as per the standard methods suggested by APHA (1995). Only high pure (AnalR Grade) chemicals and double-distilled water was used for preparing solutions for analysis. EC and $\mathrm{pH}$ were analysed in the field itself using portable digital meters. Major ions like $\mathrm{Ca}, \mathrm{Mg}, \mathrm{Na}, \mathrm{K}, \mathrm{CO}_{3}, \mathrm{HCO}_{3}, \mathrm{Cl}$, $\mathrm{SO}_{4}, \mathrm{NO}_{3}$ and $\mathrm{F}$ were analysed. A detailed description of the analytical methods used in the study is shown in Table 1. The analytical precision of the measurements of cations and anions is indicated by the ionic balance error, which has been computed on the basis of ions expressed in meq/L. The values were observed to be within the standard limit of $\pm 5 \%$. All the results are compared with standard limits recommended by World Health Organization (1993).

Aqueous speciation modeling is one of the important technique to understand the mineralization process in the groundwater. In this study we adopted the code available in the PHREEQC (Parkhurst and Appelo 1999). Saturation of minerals with the corresponding groundwater can be calculated as $\mathrm{SI}=\log \left[\mathrm{IAP} / K_{\mathrm{sp}}\right]$. Where IAP representing the ion activity product, $K_{\mathrm{sp}}$ is the equilibrium solubility product. Positive saturation indices show that the water is saturated with the mineral under consideration, however negative values indicate that the mineral is unsaturated. Spatial distribution maps were created using the kriging method in Surfer 8 software.

\section{Results and discussion}

\section{Groundwater solute concentrations}

Physical parameters in this study include water level (WL), $\mathrm{pH}$, electrical conductivity (EC) and TDS. Significant 
Table 1 Methodology adopted in the Estimation of physicochemical parameters

\begin{tabular}{ll}
\hline Parameters & Method/instruments \\
\hline $\mathrm{EC}$ and $\mathrm{pH}$ & Field kit \\
$\mathrm{Ca}$ and $\mathrm{Mg}$ & Titration using 0.05 N EDTA \\
$\mathrm{CO}_{3}$ and $\mathrm{HCO}_{3}$ & Titration using $0.01 \mathrm{~N} \mathrm{H}_{2} \mathrm{SO}_{4}$ \\
$\mathrm{Cl}$ & Titration using $0.05 \mathrm{~N} \mathrm{AgNO}_{3}$ \\
$\mathrm{Na}$ and $\mathrm{K}$ & Flame photometric method \\
$\mathrm{SO}_{4}, \mathrm{NO}_{3}$ and $\mathrm{F}$ & Spectrophotometer \\
\hline
\end{tabular}

fluctuation in WL between the post-monsoon (1.85-15.98, $\operatorname{avg}=6.22 \mathrm{mbgl}) \quad$ and pre-monsoon $(3.76-24.78$, avg $=9.3 \mathrm{mbgl}$ ) were recorded from the study area. $\mathrm{pH}$ in groundwater varied between 6.7-8.1(post-monsoon) and 7.2-8.6 (pre-monsoon). However, the average concentration of $\mathrm{pH}$ in the study area was within the permissible limit of 6.5-8.5(WHO 1993). EC of the samples ranged from, $\quad 500-3380 \mu \mathrm{S} / \mathrm{cm} \quad(\operatorname{avg}=1721 \mu \mathrm{S} / \mathrm{cm}) \quad$ and $880-2550 \mu \mathrm{S} / \mathrm{cm}$, avg $=1631 \mu \mathrm{S} / \mathrm{cm}$, in the post-monsoon and pre monsoon respectively. Ground waters samples showed a range of TDS from $320-2163 \mathrm{mg} / \mathrm{L}$ and $491-1723 \mathrm{mg} / \mathrm{L}$ in the pre- and post-monsoon respectively. In both season the average concentration of TDS was slightly higher than, WHO (1993) permissible limit, $1000 \mathrm{mg} / \mathrm{L}$. Several hydrochemical processes, which may include the movement of groundwater through rocks containing soluble minerals, concentration of water by evaporation, and contamination of water due to industrial and municipal waste disposals may cause a considerably high increase in dissolved solids (Mondal and Singh 2011).

In more than $90 \%$ of samples the charge balance error was $< \pm 5 \%$ and rest of them were well within $\pm 10 \%$.
Statistical parameters of the major ions and their comparison between post- and pre-monsoon are presented in Fig. 3. Considerable variations in the major ions were observed between both seasons. The dominance of the cations were in the order of $\mathrm{Na}>\mathrm{Mg}>\mathrm{Ca}>\mathrm{K}$. This is an indication of silicate weathering occurring in the study area with the presence of Hornblende-biotite-gneisses (Arumugam and Elangovan 2009). In many samples the Concentration of $\mathrm{Na}, \mathrm{K}$ and $\mathrm{Mg}$ exceeded their permissible limits $200 \mathrm{mg} / \mathrm{L}, 10 \mathrm{mg} / \mathrm{L}$ and $50 \mathrm{mg} / \mathrm{L}$ (BIS 1992; WHO 2011). Excess $\mathrm{Na}$ in drinkigwater causes hypertension, congenial diseases, kidney disorders and nervous disorders in human body (Ramesh and Elango 2012).

Among the major anions, the dominant one were $\mathrm{Cl}$ and $\mathrm{HCO}_{3}$, with an order of $\mathrm{Cl}>\mathrm{HCO}_{3}>\mathrm{SO}_{4}>\mathrm{NO}_{3}>\mathrm{F}$. However, this order has been changed to $\mathrm{HCO}_{3}>-$ $\mathrm{Cl}>\mathrm{SO}_{4}>\mathrm{NO}_{3}>\mathrm{F}$ in samples were low pollution were expected. Higher concentration of $\mathrm{Cl}$ was observed in few samples especially in the post-monsoon season, which may cause salty taste and has a laxative effect (Bhardwaj and Singh 2011). Fluoride concentration was well within the permissible limit $(1.5 \mathrm{mg} / \mathrm{L}$; WHO 2011) in all the samples, discarding the major health issue fluorosis (Sajil Kumar 2012). However, nearly $50 \%$ of the samples have exceeded the permissible limit nitrate $(50 \mathrm{mg} / \mathrm{L}$ ) (WHO 2011) rising serious impacts to the human health i.e. Methaemoglobinaemia (Comly 1987). Over all hydrogeochemical parameters suggesting that chemical quality of the groundwater is controlled by the semi-arid climate, geological formations, untreated effluents from the textile industries and agricultural sources such as fertilizer and irrigation return flows. Similar observations were made by Arumugam and Elangovan (2009) from Tiruppur district.
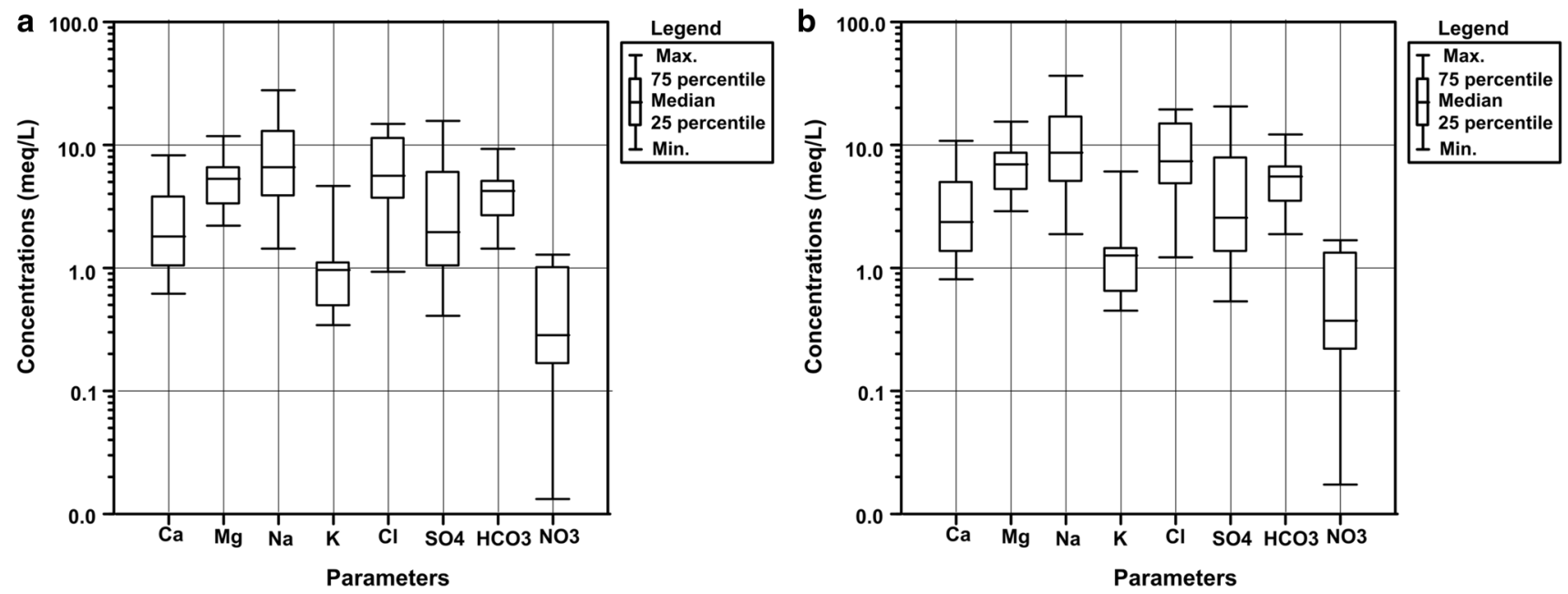

Fig. 3 Box plot showing the distribution of the statistical parameters 


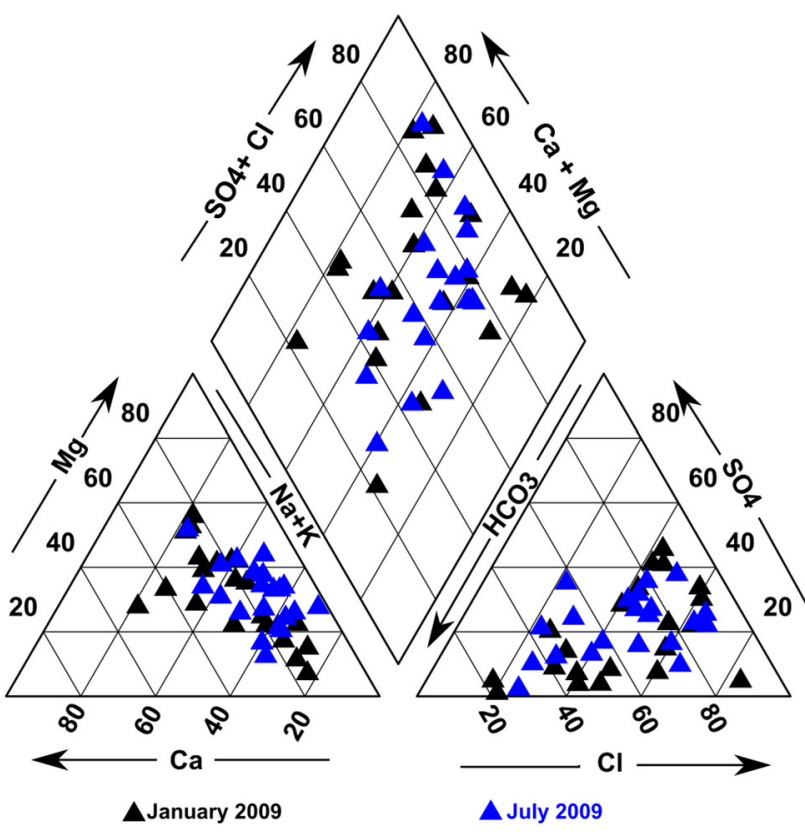

Fig. 4 Piper plot showing the hydrochemical facies in Dharapuram area

\section{Groundwater types in the study area}

Groundwater types and their seasonal variation may be useful in narrow down or confirming the above mentioned sources and processes. For this purpose a piper trilinier diagram (Piper 1953) were plotted using the hydrochemical data (Fig. 4). In both season, dominant water type was $\mathrm{Na}-\mathrm{Cl}$ and rest of the samples were dominated by $\mathrm{Ca}-\mathrm{Cl}$ and mixed $\mathrm{Ca}-\mathrm{Mg}-\mathrm{Cl}$ type of water. This trend is clearly showing dominance of $\mathrm{Na}-\mathrm{Cl}$ rich effluent from the textile industries and their interaction with the natural groundwater. Geologically the region comprises of Gneisses and charnockites and devoid of any evaporates deposits. This is strengthening the argument that the groundwater is affected impact of textile industries on water chemistry. The critical analysis of the water types hits the possibility of a cation exchange that produces $\mathrm{Ca}-\mathrm{Cl}$ or $\mathrm{Ca}-\mathrm{Mg}-\mathrm{Cl}$ type of water types from the $\mathrm{Na}-\mathrm{Cl}$ rich water from the industry. Apart from the $\mathrm{Na}$ and $\mathrm{Cl}$, a high concentration of $\mathrm{Ca}$ (up to $320 \mathrm{mg} / \mathrm{L}$ ) in the untreated effluent has been reported by Ranganathan et al. (2007). This may be stimulating the direct ion exchange process; $\mathrm{Ca}$ from the effluent is replaces $\mathrm{Na}$ from the country rock, which is originated by the silicate weathering.

Identification of chemical processes in groundwater Gibbs plot (Gibbs 1970) is widely used by the hydrochemists to assess the dominance of various processes such as precipitation, rock-water interactions and evaporation. There were not much seasonal variation is observed. However, it could diffrenciate the processes like rock-water interaction and evaporation. Majority of the samples were fall in the rock dominant and evaporation field (see Fig. 5). This shows that groundwater in the study area is largelly controlled by weathering of minerals present in the country rock and the evaporation dominated processes and irrigatuion return flow. Elevated conentration of $\mathrm{NO}_{3}$ in many samples is supporting the argument that irrigation return flow has a considerable influence on water chemistry.

It is evident from the Gibbs plot that rockwater interaction is contributing more than any other process. Geology of the study area and the pollution sources from the textile suggesting three processes like silicate weathering, carbonate dissolution and evaporation. A bivariate plot between $\mathrm{Ca} / \mathrm{Na}$ and $\mathrm{HCO}_{3} / \mathrm{Na}$ have been drawn to illustrate the control of these processes (Belkhiri et al. 2010; Biswas et al. 2012; see Fig. 6).

$$
\begin{gathered}
2 \mathrm{NaAlSi}_{3} \mathrm{O}_{8}+11 \mathrm{H}_{2} \mathrm{O} \leftrightarrow \mathrm{Al}_{2} \mathrm{Si}_{2} \mathrm{O}_{5}(\mathrm{OH})_{4}+2 \mathrm{Na}^{+}+2 \mathrm{HCO}_{3} \mathrm{H}_{4} \mathrm{SiO}_{4} \\
\text { Albite }
\end{gathered}
$$

Result shows that silicate weathering remains the principal process under fluctuating water level from rainy season to
Fig. 5 Mechanisms controlling the groundwater chemistry, a post-monsoon, $\mathbf{b}$ pre-monsoon
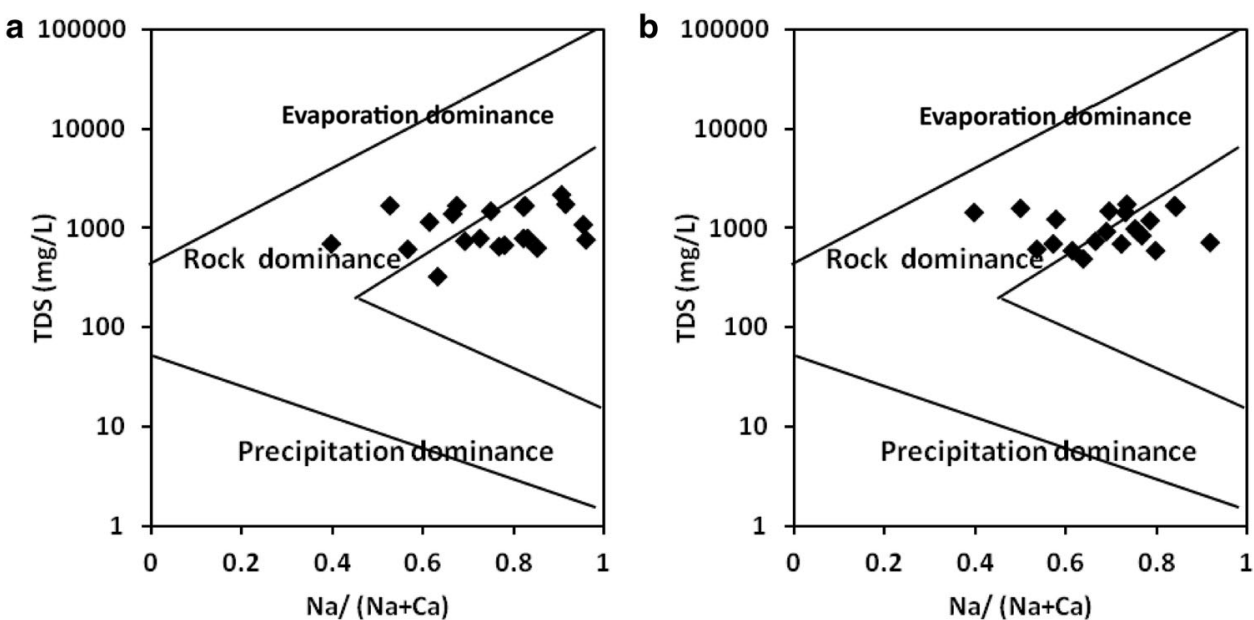

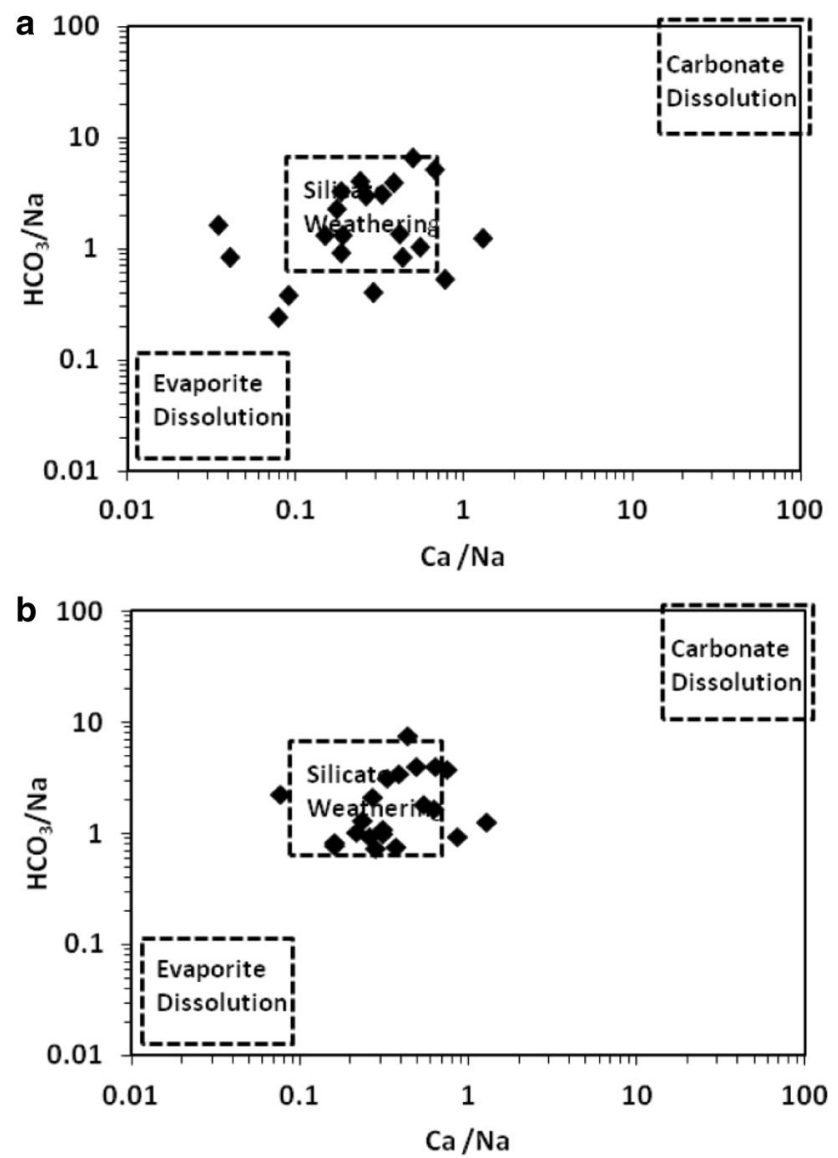

Fig. 6 Bivariate plot between $\mathrm{Ca} / \mathrm{Na}$ and $\mathrm{HCO}_{3} / \mathrm{Na}$ identifying the mineral weathering processes in the groundwater of the study area, a post-monsoon, $\mathbf{b}$ pre-monsoon

summer. However, in post- monsoon few samples falling near the evaporation field in Fig. 6, suggesting the influence of textile waste/or irrigation return flow with high salinity. This is normally occurs when the water level increases, this may bring up the salinity from the deep aquifers. The other explanation may be the due to the mixing between the high saline effluent with the monsoon rain and subsequent recharge to the groundwater. However, in the pre-monsoon season the groundwater flow will be less and will increase groundwater residense time in the aquifer. Here the interation between groundwater and the weathernd silicate minerals may generate variety of chemical reactions including dissolution, deposition and cation exchange etc. However, the driving force for these processes and mobility of the ions are purely depends on the existing hydrochemical kinetics in the groundwater environment.

\section{Impact of water level fluctuations on solute concentration}

Attempts have been made to decipher the changes in hydrochemistry with water level fluctuations. Figure $7 a-d$ illustrates the spatial variation of water level and electrical conductivity values. In general, those wells affected by the textile effluents and irrigation return flows showed a relative increase in the EC values with increase in water level (Type 1). At the same time wells in natural condition expressed a tendency to increase the EC with lowering of water table (Type 2). Contrary to both these behaviors, there were samples without any considerable variation in the electrical conductivity values (Type 3 ). The underlying facts of these three types of samples may be revealed by calculating the chemical activity as well as the saturation state of mineral species. Samples 1, 2 and 8 were selected as representatives of the Type 1,2 and 3 respectively and their hydrochemical characteristics are summarized in the Table 2. Aqueous speciation modeling was carried using PHREEQC for these three samples (see Table 3).

Ionic concentration in the groundwater was decreased with lowering of water table or in other words increased with increased water table (Type 1; e.g. sample no. 1). Most of the dry minerals deposits available from the preceding summer season will be washed and taken into solution by the water level rise (Rajmohan and Elango 2006). This may be the major reason for the type 1 water types. Moreover, saturation indices of mineral species calculated for this sample showed significant variation in both season (see Fig. 8a). Carbonate mineral species such as aragonite calcite and dolomite were under saturated in post-monsoon season. This may results in the dissolution of ions like $\mathrm{Ca}, \mathrm{Mg}$ and $\mathrm{HCO}_{3}$ available in the weathered country rock with the monsoon recharge. SI of fluorite was undersaturated in both seasons, indicating that the groundwater is capable of dissolving more $\mathrm{F}$ minerals. However, the level of $\mathrm{F}$ in the study area is below permissible limit $(1.5 \mathrm{mg} / \mathrm{L})$, suggesting that lack of $\mathrm{F}$ minerals or appropriate geochemical conditions for $\mathrm{F}$ mobilization in groundwater environment. In the summer season the groundwater level and the flow rate were reduced considerably which lead to the deposition of many carbonate minerals and this may cause retardation in ionic constituents in the groundwater.

In the sample 2, ionic constituents showed an increase with relative decrease in the water level (type 2). This is a consequence of the evaporation-crystallization reactions due to the elevated heat during the summer and the relatively shallow depth of the wells. However, the low ionic concentration in this well during the monsoon season (higher water level) is due to the effect of dilution. This must be noted that this well is devoid of any surficial pollution sources. The arguments were confirmed by the Results of SIs, showing that groundwater is oversaturated in the low water level season for the carbonate minerals (see Fig. 8b). The variation in the hydrochemistry is largely controlled by the dissolution and deposition of 

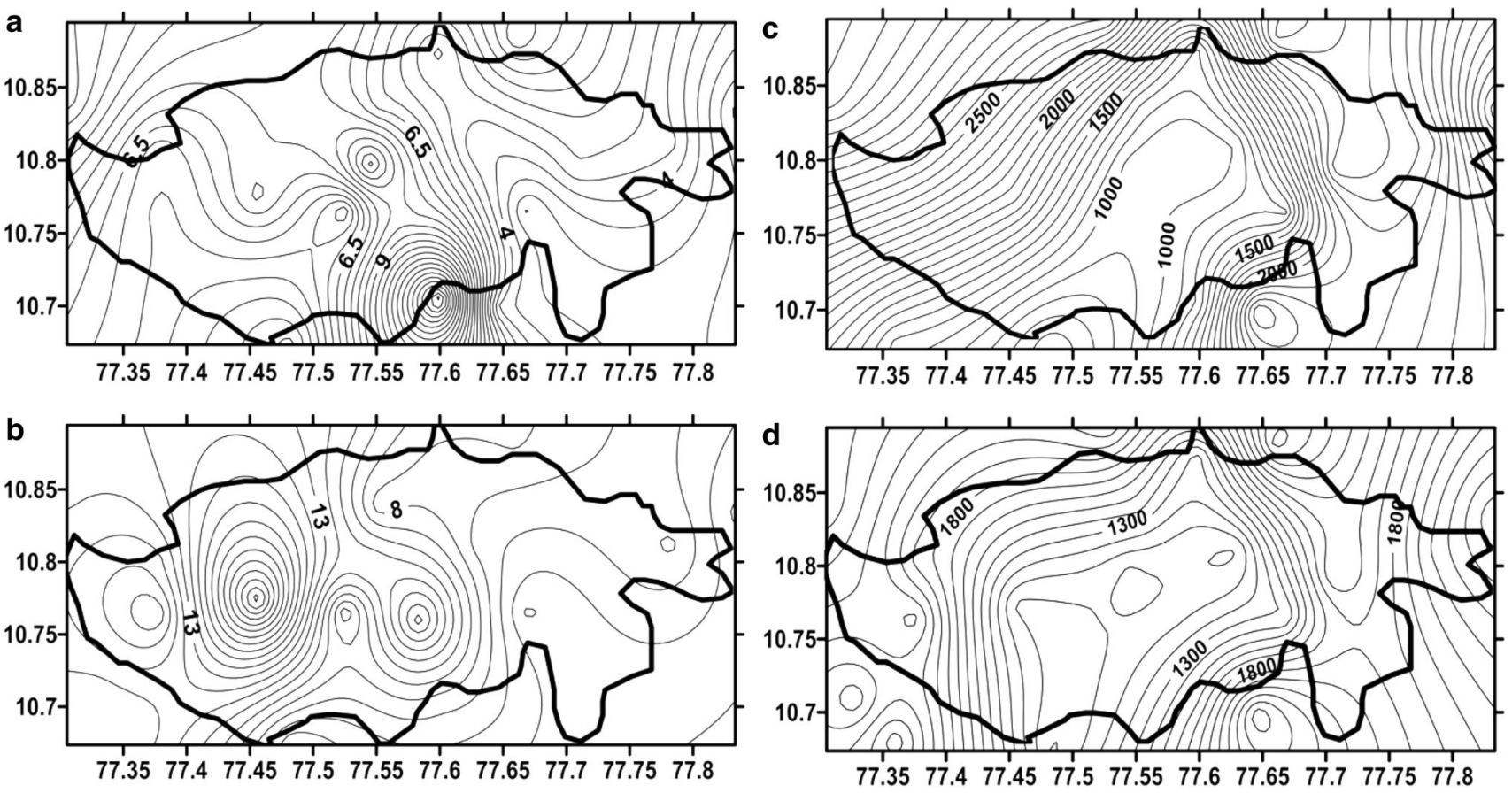

Fig. 7 Spatial distribution of water level $(\mathbf{a}, \mathbf{b})$ and electrical conductivity $(\mathbf{c}, \mathbf{d})$ in the post and pre-monsoon respectively

Table 2 Seasonal variation of water level and hydrogeochemistry of the three selected groundwater samples

\begin{tabular}{|c|c|c|c|c|c|c|c|c|c|c|c|c|c|c|c|}
\hline S. no & Season & WL & $\mathrm{pH}$ & $\mathrm{EC}$ & TDS & TH & $\mathrm{Ca}$ & $\mathrm{Mg}$ & $\mathrm{Na}$ & K & $\mathrm{Cl}$ & $\mathrm{SO}_{4}$ & $\mathrm{HCO}_{3}$ & $\mathrm{NO}_{3}$ & F \\
\hline \multirow[t]{2}{*}{1} & Post- & 6.25 & 7.9 & 1670 & 1069 & 185 & 12 & 38 & 294 & 39 & 255 & 288 & 244 & 1 & 1.2 \\
\hline & Pre- & 12.71 & 8.5 & 1193 & 1820 & 440 & 52 & 75 & 221 & 38 & 248 & 97 & 287 & 65 & 1.44 \\
\hline \multirow[t]{2}{*}{2} & Post- & 5.55 & 7.9 & 1090 & 698 & 395 & 90 & 41 & 69 & 20 & 163 & 206 & 85 & 14 & 0.78 \\
\hline & Pre- & 12.97 & 7.6 & 2370 & 1585 & 810 & 160 & 100 & 184 & 33 & 383 & 379 & 171 & 59 & 0.8 \\
\hline \multirow[t]{2}{*}{8} & Post & 10.81 & 7.2 & 1850 & 1232 & 590 & 116 & 73 & 184 & 15 & 269 & 211 & 305 & 48 & 1.22 \\
\hline & Pre- & 5.48 & 7.8 & 1702 & 2660 & 860 & 160 & 112 & 207 & 14 & 461 & 384 & 110 & 58 & 1 \\
\hline
\end{tabular}

Table 3 Results of geochemical modeling of the three selected samples

\begin{tabular}{|c|c|c|c|c|c|c|}
\hline \multirow[t]{2}{*}{ Phase } & \multicolumn{2}{|l|}{ SI1 } & \multicolumn{2}{|l|}{ SI2 } & \multicolumn{2}{|l|}{ SI8 } \\
\hline & Post- & Pre- & Post- & Pre- & Post- & Pre- \\
\hline Anhydrite $\left(\mathrm{CaSO}_{4}\right)$ & -2.31 & -2.22 & -1.55 & -1.23 & -1.24 & -1.54 \\
\hline Aragonite $\left(\mathrm{CaCO}_{3}\right)$ & -0.48 & 1.08 & -0.01 & 0.14 & 0.14 & -0.1 \\
\hline Calcite $\left(\mathrm{CaCO}_{3}\right)$ & -0.33 & 1.23 & 0.14 & 0.29 & 0.29 & 0.05 \\
\hline $\mathrm{CaMg}\left(\mathrm{CO}_{3}\right)_{2}$ & 0.13 & 2.91 & 0.22 & 0.66 & 0.7 & 0.19 \\
\hline Fluorite $\left(\mathrm{CaF}_{2}\right)$ & -1.74 & -1.01 & -1.19 & -1.09 & -0.91 & -0.79 \\
\hline Gypsum $\left(\mathrm{CaSO}_{4}: 2 \mathrm{H}_{2} \mathrm{O}\right)$ & -2.07 & -1.98 & -1.31 & -0.99 & -1 & -1.31 \\
\hline Halite $(\mathrm{NaCl})$ & -5.73 & -5.88 & -6.54 & -5.78 & -5.65 & -5.92 \\
\hline
\end{tabular}

carbonate minerals, probably sourced from the weathering of hard rocks. Sample 8 seems to be stable during the water level fluctuation occurred under the influence of seasonal variation. However the SI of these samples showed a close resemblance with those of sample 2 . The probable explanation may be this sample is representing the unaltered hard rock terrain and also devoid of any anthropogenic influences. 

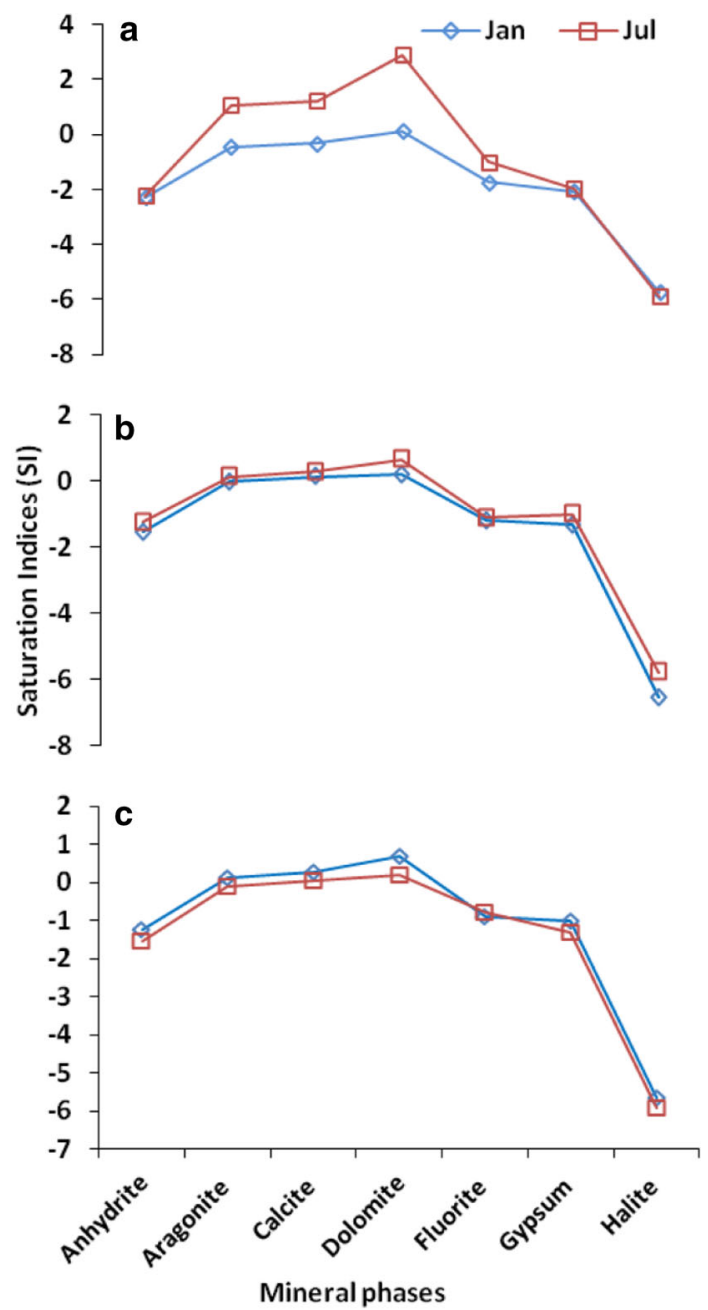

Fig. 8 The seasonal variation in hydrochemistry of three selected wells in the study area. Chemical constitutes were, a increases with water level increase (type 1; Well no. 1), b chemical constitutes were increases with increase in water level (type 2; Well no. 2), c chemical constitutes were unaltered with water level fluctuation (type 3; Well no. 8)

\section{Conclusions}

Hydrogeochemical analysis in conjunction with graphical methods and aqueous speciation modeling was useful in differentiating the chemical characteristics of groundwater under fluctuating water level. Hydrochemistry showed considerable variation in spatially and limited temporal variation. $\mathrm{Na}-\mathrm{Cl}$ was the major water type in the study area, with contribution from $\mathrm{Ca}-\mathrm{Cl}$ and $\mathrm{Ca}-\mathrm{Mg}-\mathrm{Cl}$. The mixing of $\mathrm{Ca}$ and $\mathrm{Mg}$ with $\mathrm{Cl}$ sourced from the anthropogenic inputs are evident from the $\mathrm{Ca}-\mathrm{Cl}$ and $\mathrm{Ca}-\mathrm{Mg}-\mathrm{Cl}$ type of water. Results from Gibbs and bivariate plots suggested that silicate weathering is the dominant process controlling the hydrochemistry. Spatial variation maps of EC are compared with the Water level maps. Three wells were selected based on Water level \& EC to study the impact of water level variations on hydrochemistry. There were three major patters were observed; type 1 , increased with elevation in water level; type 2 increased with decreasing water level; type 3 no significant changes with WL fluctuation. Saturation states in post- (undersaturated) and pre-monsoon (oversaturated) season's shows the significance of carbonate mineral dynamics on hydrochemistry. Higher concentration of $\mathrm{Cl}$ and $\mathrm{NO}_{3}$ may be attributed to untreated high saline textile effluents and may also from the irrigation return flow. Absence of conventional sources of $\mathrm{Cl}$ like evaporates and coastal zones confirm this argument. It is observed that, the water level rise in at least few locations have not improved the water quality, in contrast deteriorated.

\section{References}

APHA (1995) Standard methods for estimation of water and waste water, 19th edn. American Public Health Association, Washington, $\mathrm{DC}$

Arumugam K, Elangovan K (2009) Hydrochemical characteristics and groundwater quality assessment in Tiruppur Region, Coimbatore District, Tamil Nadu, India. Environ Geol 58:1509-1520

Arunprakash M, Giridharan L, Krishnamurthy RR, Jayaprakash M (2014) Impact of urbanization in groundwater of south Chennai City, Tamil Nadu, India. Environ Earth Sci 71(2):947-957

Belkhiri L, Boudoukha A, Mouni L, Baouz T (2010) Application of multivariate statistical methods and inverse geochemical modeling for characterization of groundwater-a case study: ain Azel plain (Algeria). Geoderma 159:390-398

Bhardwaj V, Singh DS (2011) Surface and groundwater quality characterization of Deoria District, Ganga Plain, India. Environ Earth Sci 63:383-395

BI (1992) Indian standard specifications for drinking water. BIS: 10500. http://hppcb.gov.in/EIAsorang/Spec.pdf

Biswas A, Nath B, Bhattacharya P, Halder D, Kundu AK, Mandal U, Mukherjee A, Chatterjee D, Mörth CM, Jacks G (2012) Hydrogeochemical contrast between brown and grey sand aquifers in shallow depth of Bengal Basin: consequences for sustainable drinking water supply. Sci Total Environ 431:402-412

Bjerg PL, Christensen TH (1992) Spatial and temporal small-scale variation in groundwater quality of a shallow sandy aquifer. J Hydrol 131:133-149

Buragohain M, Bhuyan B, Sarma HP (2010) Seasonal variations of lead, arsenic, cadmium and aluminium contamination of groundwater in Dhemaji district, Assam, India. Environ Monit Assess 170:345-351

Comly HH (1987) Cyanosis in infants caused by nitrates in well water. J Am Med Assoc 257:2788-2792

Gibbs RJ (1970) Mechanisms controlling worlds water chemistry. Science 170:1088-1090

Giridharan L, Venugopal T, Jayaprakash M (2008) Evaluation of the seasonal variation on the geochemical parameters and quality assessment of the groundwater in the proximity of River Cooum, Chennai, India. Environ Monit Assess 143:161-178

Holz GK (2009) Seasonal variation in groundwater levels and quality under intensively drained and grazed pastures in the Montagu catchment, NW Tasmania. Agric Water Manag 96:255-266 
Jayalakshmi B, Ramachandramoorthy T, Paulraj A (2014) Statistical interpretation on seasonal variations of groundwater quality in Ramanathapuram coastal tract, Tamil Nadu, India. Environ Earth Sci 72(4):1271-1278

Karmegam U, Chidamabram S, Sasidhar P, Manivannan R, Manikandan S, Anandhan P (2010) Geochemical characterization of groundwater's of shallow coastal aquifer in and around Kalpakkam, South India. Res J Environ Earth Sci 2(4):170-177

Laluraj CM, Gopinath G (2006) Assessment on seasonal variation of groundwater quality of phreatic aquifers-a River Basin system. Environ Monit Assess 117:45-57

Mohapatra PK, Vijay R, Pujari PR, Sundaray SK, Mohanty BP (2011) Determination of processes affecting groundwater quality in the coastal aquifer beneath Puri city, India: a multivariate statistical approach. Water Sci Technol 64:809-817

Mondal NC, Singh VP (2011) Hydrochemical analysis of salinization for a tannery belt in Southern India. J Hydrol 405:235-247

Parkhurst DL, Appelo CJ (1999) User's guide to PHREEQC (version 2)-a computer program for speciation, batch-reaction, onedimensional transport, and inverse geochemical calculations. Water Resources Investigations Report 99-4259. United States Geological Survey, Washington, DC

Piper AM (1953) A graphic procedure for the geo-chemical interpretation of water analysis. USGS Groundwater, Note no. 12

Rajmohan N, Elango L (2006) Hydrogeochemistry and its relation to groundwater level fluctuation in the Palar and Cheyyar river basins, southern India. Hydrol Process 20(11):2415-2427

Ramesh K, Elango L (2012) Groundwater quality and its suitability for domestic and agricultural use in Tondiar river basin, Tamil Nadu, India. Environ Monit Assess 184(6):3887-3899
Ranganathan K, Karunagaran K, Sharma DC (2007) Recycling of wastewaters of textile dyeing industries using advanced treatment technology and cost analysis-case studies. Resour Conserv Recycl 50:306-318

Sajil Kumar PJ (2012) Assessment of fluoride contamination in groundwater as precursor for electrocoagulation. Bull Environ Contam Toxicol 89:172-175

Sajil Kumar PJ, Jose A, James EJ (2013) Spatial and seasonal variation in groundwater quality in parts of Cuddalore District, South India. Natl Acad Sci Lett 36(2):167-179

Subba Rao N (2006) Seasonal variation of groundwater quality in a part of Guntur District, Andhra Pradesh, India. Environ Geol 49:413-429

Umar R, Ahmed I, Alam F, Khan MM (2009) Hydrochemical characteristics and seasonal variations in groundwater quality of an alluvial aquifer in parts of Central Ganga Plain, Western Uttar Pradesh, India. Environ Geol 58:1295-1300

Vasanthavigar M, Srinivasamoorthy K, Prasanna MV (2012) Evaluation of groundwater suitability for domestic, irrigational, and industrial purposes: a case study from Thirumanimuttar river basin, Tamilnadu, India. Environ Monit Assess 184:405-420

WHO (2011) Guidelines for drinking-water Quality, IV edn. World Health Organization, Geneva, p 340

World Health Organization (WHO) (1993) Guidelines for drinking water quality, 2nd ed, vol 1. Recommendations, Geneva

Zhang B, Song X, Zhang Y, Han D, Tang C, Yu Y, Ma Y (2012) Hydrochemical characteristics and water quality assessment of surface water and groundwater in Songnen plain, Northeast China. Water Res 46:2737-2748 